Biol. Neonate 1972;20:I-VI

\title{
Contents, Vol. 20, 1972
}

\section{Contents}

Ackerman, B. D.: see Ullrich, J. R.

Ackerman, B. D.; Sosna, Marilyn M. and Ullrich, J. R.: A Technique for

Serial Sampling of Umbilical Artery Blood at Birth 458

Adlard, B. P. F.: see Smart, J. L.

Alexander, G.; Bell, A. W. and Hales, J. R. S.: The Effect of Cold Exposure on the Plasma Levels of Glucose Lactate, Free Fatty Acids and Glycerol and on the Blood Gas and Acid-Base Status in Young Lambs

Alexander, G.; Thorburn, G.; Nicol, D. and Bell A. W.: Survival, Growth and the Metabolic Response to Cold in Prematurely Delivered Lambs 1 Anderson-Huntington, Rebecca B. and Rosenblith, Judy F.: Report on Newborns with Questionable Light Sensitivity

Avery, Mary Ellen: see Taeusch, H.W., jr.

Bell, A. W.: see Alexander, G.

Bergman, L.: Plasma Calcium Fractions during the First Days of Life with Special

Reference to Neonatal Hypocalcaemia 346

Blankenship, W.J.: see Stahlman, M.

Brann, A.W., jr.: see Rivera, A., jr.

Cápková, A.: see Prùzková, V.

Chan, H.: see Widdowson, E. M.

Cordero, L., jr.: Heart Rate Changes During the First Hour of Life 270

Csáki, P.: see Hevér, Ö.

Cutts, J. H.: see Leeson, C. R.

Dahl, M. and Välimäki, I.: Postural Effect on Respiration and Heart Rate of

Newborn Infants. An Impedance Pneumographic Study 161

Dahlquist, G.; Persson, U., and Persson, B.: The Activity of D-ß-Hydroxybutyrate Dehydrogenase in Fetal, Infant and Adult Rat Brain and the In

fluence of Starvation 40

Deconinck, B.: see Ponté, C.

Dhindsa, D. S.; Hoversland, A. S. and Templeton, J.W.: Postnatal Changes in

Oxygen Affinity and Concentrations of 2,3-Diphosphoglycerate in Dog

Blood 226

Dobbing, J.: see Smart, J. L.

Dolezalová, Vëra : see Kucera, J.

Drian, M.J.: see Privat, A.

Edwards, N. K.: see Perlstein, P. H.

Feuer, G.: see Kardish, R.

Fourlinnie, J. C.: see Ponté, C.

Gaudier, B.: see Ponté, C. 
Gray, J.: see Stahlman, M.

Gruner, J. E.: see Privat, A.

Hales, J. R. S.: see Alexander, G.

Harrison, G. E.: see Widdowson, E. M.

IV

Contents

Hevér, ö.; Vadász, G.; Hollo, T. and Csáki, P.: Determination of Haptoglobin

Level in Umbilical Cord Blood of Newborns. Haptoglobin Types of Ma

ternal and Umbilical Cord Blood Pairs 245

Hodr, J.: see Stembera, Z. K.

Hollo, T.: see Hevér, ö.

Horská, S.: see Stembera, Z. K.

Hoversland, A. S.: see Dhindsa, D. S.

Hunter, D. J. S. and Isles, T. E.: The Insulinogenic Effect of Glucagon in the

Newborn 74

Ing, R. M. Y.: see Jones, W. R.

Isles, T. E.: see Hunter, D. J. S.

Jährig, K.; Zöllner, H. and Margies, Dietlind: Osmolar Clearance and Clear

ance of Total Electrolytes in Newborn Infants 93

Janda, J.: see Stembera, Z. K.

Jirásek, J.: see Prûzková, V.

Jones, W. R.; Kaye, M. D. and Ing, R. M. Y.: The Lymphoid Development of the Fetal and Neonatal Appendix 334

Josso, Nathalie: Evolution of the Müllerian-Inhibiting Activity of the Human

Testis. Effect of Fetal, Peri-Natal and Post-Natal Human Testicular

Tissue on the Müllerian Duct of the Fetal Rat in Organ Culture 368

Jumawan, Jocelyn; Koldovsky, O. and Palmieri, M.: Postnatal Changes of

$\alpha$-Galactosidase Activity in the Small Intestine of the Rat 380

Jungreis, E.: see Schenker, J. G.

Kardish, R. and Feuer, G.: Relationship between Maternal Progesterones and the Delayed Drug Metabolism in the Neonate $\quad 58$

Kaye, M. D.: see Jones, W. R.

Kittrich, M.: see Stembera, Z. K.

Klujber, L.; Mestyán, J.; Sulyok, E. and Soltész, G.: Urinary Hydroxyproline

Excretion in Normally Grown and Growth-Retarded Newborn Infants . 196

Koldovsky, O.: see Jumawan, Jocelyn

Kuõera, J. and Dolezalová, Vëra: Prenatal Development of Malformed Fetuses

at 28-42 Weeks of Gestational Age (Anencephalus, Hydrocephalus,

Down's Syndrome, Cleft Lip and Palate, and Hypospadias). I. Weight

Gains 253

Lambrechts, A.: see Senterre, J.

Larks, Golda G.: see Larks, S. D.

Larks, S. D. and Larks, Golda G.: Factors Associated with Birth Condition... 134

Larroche, Jeanne-Claudie: Post-Haemorrhagic Hydrocephalus in Infancy.

Anatomical Study 287

Laster, L.: see Volpe, J.J. 
Lecce, J.G.: see Rundell, J.O.

Leeson, C. R. and Cutts, J. H.: The Postnatal Development of the Rabbit Liver 404

Lester, E. P.: see Shanklin, D. R.

Malan, A. F.: see Stahlman, M.

Manzke, H.: Relationship between Extracellular and Intracellular Hydrogen Ion

Concentrations and Hemoglobin Oxygen Affinity in the Blood of Pre

mature Infants with RDS 321

Contents V

Margies, Dietlind: see Jährig, K.

Martinez-de Jesus, J.: see Rivera, A., jr.

Masera, G.; Piceni Sereni, L.; Perletti, L. and Sereni, F.: Influence of Nutritional Factors on

Plasma Concentration of Factor II and Factors VII-X and on the Rate of Synthesis of Serum

Albumin in Newborn Rabbits .. 436

Mestyán, J.: see Klujber, L.

Milner, R. D.G.: see Widdowson, E. M.

Mitchell, R.G.: see Shennan, A.T.

Mourek, J.: see Prûzková, V.

Myers, R. E.: see Rivera, A., jr.

Nicol, D.: see Alexander, G.

Palmieri, M.: see Jumawan, Jocelyn

Perletti, L.: see Masera, G.

Perlstein, P. H.; Edwards, N. K. and Sutherland, J. M.: Age Relationship

to Thermal Patterns on the Backs of Cold-stressed Infants 127

Persson, B.: see Dahlquist, G.

Persson, U.: see Dahlquist, G.

Piceni Sereni, L.: see Masera, G.

Polishuk, W. Z.: see Schenker, J. G.

Ponté, C; Gaudier, B.; Deconinck, B. and Fourlinnie, J.C.: Blood Glucose,

Serum Insulin and Growth Hormone Response to Intravenous Admi

nistration of Arginine in Premature Infants 262

Porter, J. F.: see Shennan, A.T.

Pribylova, Hana and Rylander, Eva: Free Fatty Acids, Glycerol, Glucose and

ß-Hydroxybutyrate of Plasma of Infants Protected from Cooling and

Exposed to Cold at Various Times after Birth 425

Privat, A.; Drian, M.J. and Gruner, J. E.: Retardation in the Outgrowth of

Dysmature Rat Cerebellum Cultivated in vitro 414

PrõzKovÁ, V.; Jirásek, J.; Mourek, J.; Zwinger, A. and Capková, A.: Oxygen

Consumption in Some Human Fetal Tissues 170

Randall, G. C. B.: pH Values and Blood-Gas Tensions in the Normal Piglet

during the First 48 Hours of Life $\quad 68$

Rivera, A., jr; Brann, A.W., jr.; Martinez-de Jesus, J. and Myers, R. E.:

Glycogen Content of Vital Organs of Newborn Monkeys Recovering

from Asphyxia 22

Rosenblith, Judy F.: see Anderson-Huntington, Rebecca B. 
Rundell, J.O. and Lecce, J.G.: Independence of Intestinal Epithelial Cell Turn over from Cessation of Absorption of Macromolecules (Closure) in the Neonatal Mouse, Rabbit, Hamster and Guinea Pig 51

Rylander, Eva: see Pribylova, Hana

Schenker, J. G.; Jungreis, E. and Polishuk, W. Z.: Maternal and Fetal Serum

Copper Levels at Delivery 189

Scott, K. E.: see Wong, K. S.

Senterre, J. and Lambrechts, A.: Nitrogen, Fat and Minerals' Balances in Premature Infants Fed Acidified or Nonacidified Half-skimmed Cow Milk. 107

Sereni, F.: see Masera, G.

VI

Contents

Shanklin, D. R. and Lester, E. P.: On the Pulmonary Toxicity of Oxygen. II.

The Effect of the Second Gas 140

Shennan, A.T.; Porter, J. F. and Mitchell, R.G.: Plasma Kinin and Kininogen

Levels in Newborn Infants with Respiratory Distress 101

Shepard, F. M.: see Stahlman, M.

Smart, J. L.; Adlard, B. P. F. and Dobbing, J.: Effect of Maternal Under-

nutrition and other Factors on Birth Weight in the Rat 236

Soltész, G.: see Klujber, L.

Sosna, Marilyn M.: see Ackerman, B. D.

Stahlman, M.; Blankenship, W.J.; Shepard, F. M.; Gray, J.; Young, W.C. and Malan, A. F.: Circulatory Studies in Clinical Hyaline Membrane Dis ease 300

Stembera, Z. K.; Hodr, J.; Kittrich, M. and Janda, J.: Fetoplacental Circula tion in the Umbilical Cord when Coiled around the Fetal Neck 120

Stembera, Z. K. and Horská, S.: The Influence of Coiling of the Umbilical Cord around the Neck of the Fetus on its Gas Metabolism and Acid-Base

Balance 214

Sugg, J.: see Taeusch, H.W., jr.

Sulyok, E.: see Klujber, L.

Sutherland, J. M.: see Perlstein, P. H.

Taeusch, H. W., jr.; Avery, Mary Ellen and Sugg, J.: Premature Delivery with out Accelerated Lung Development in Fetal Lambs Treated with Long-

acting Methylprednisolone 85

Templeton, J.W.: see Dhindsa, D. S.

Thorburn, G.: see Alexander, G.

Ullrich, J. R.: see Ackerman, B. D.

Ullrich, J. R. and Ackerman, B. D.: Changes in Umbilical Artery Blood Gas

Values with the Onset of Respiration 446

Vadász, G.: see Hevér, Ö.

Välimäki, I.: see Dahl, M.

Volpe, J.J. and Laster, L.: Transsulfuration in Fetal and Postnatal Mammalian

Liver and Brain. Cystathionine Synthase, its Relation to Hormonal In

fluences, and Cystathionine 385 
Widdowson, E. M.; Chan, H.; Harrison, G. E. and Milner, R. D.G.: Accumulation of Cu, Zn, $\mathrm{Mn}, \mathrm{Cr}$ and $\mathrm{Co}$ in the Human Liver before Birth .. 360

Wong, K. S. and Scott, K. E.: Fetal Growth at Sea Level 175

Young, W. C.: see Stahlman, M.

Zachman, R. D.: The Enzymes of Lecithin Bio-Synthesis in Human Newborn

Lungs. II. Methionine-Activating Enzyme and Phosphatidyl Methyl-

transferase 448

Zöllner, H.: see Jährig, K.

Zwinger, A.: see PRûzková, V.

Book Review 159

Varia 160 